\title{
Colonialismo e anticolonialismo em contos angolanos de João Melo
}

\author{
André Luis Mitidieri' \\ Rejane Seitenfuss Gehlen ${ }^{2}$
}

O importante não é aquilo que fazem de nós, mas o que
nós mesmos fazemos do que os outros fizeram de nós.

Jean-Paul Sartre

Em significativa fração, as literaturas africanas de língua portuguesa parecem demarcar-se pelo estabelecimento de relações entre o literário e o social, singularmente reveladoras do papel esperado das obras literárias no período pós-independência, ou seja, de comprometimento com suas respectivas comunidades de vida e discurso. Nesse conjunto, a literatura angolana mostra-se comprometida com a construção identitária de uma nação e dos indivíduos que a constituem, assumindo traços de um processo de descolonização levado a efeito sob diferentes formas. A utilização de estratégias discursivas, a contrapelo do cânone europeu, assinala um percurso que abrange a releitura do imaginário popular no contexto da Angola do século xxI. Por outro lado, há a reconstituição crítica de um passado colonial, relido e contemporizado através do enfoque a conflitos étnicos - herança da ideologia colonial - e relações de embate entre negros e brancos, mulheres e homens.

A literatura engajada, na definição de Jean-Paul Sartre, caracteriza-se pela escolha ética, responsabilidade, urgência e referência ao tempo presente, aos interesses sociais e políticos da época, revelando um escritor preocupado com o sentido político do seu fazer, como se receasse pela não necessidade de uma literatura voltada sobre si própria, dissociada do mundo. A produção de escritores que compartilham desse pensamento representa a alteridade constituída por vozes e histórias silenciadas de sujeitos que não logram alcançar a cidadania e falam da margem, revelando um universo pessoal e familiar que se constitui em metonímia do país. Os textos situados nesse panorama são construídos numa perspectiva convexa que não perde de vista o

\footnotetext{
Doutor em Letras (teoria da literatura) e professor da Universidade Estadual de Santa Cruz (UESC), Ilhéus, BA, Brasil. E-mail: mitidierister@gmail.com

2 Doutoranda em Letras: Literaturas Portuguesa e Luso-africanas pela Universidade Federal do Rio Grande do Sul (Ufrgs), Porto Alegre, Rs, Brasil. E-mail: rejanegehlen@yahoo.com.br
} 
horizonte angolano, ao contrário, toma-o como referência no diálogo com outras literaturas e culturas.

A causa que defendem mostra-se como objetivo aparente em seu discurso, uma vez que a finalidade profunda é comprometer-se sem o aparentar. Tomando a literatura como

um discurso tão curiosamente engendrado que equivale ao silêncio; um pensamento que se contenta em si mesmo [...], um momento histórico que, pelos aspectos ocultos que revela, remete de súbito ao homem eterno; um perpétuo ensinamento, mas que se dá contra a vontade expressa daqueles que ensinam (SARTRE, 1993, p. 28).

A respeito dessa relação, Sartre destaca que "a obra de arte, vista de qualquer ângulo, é um ato de confiança na liberdade dos homens" (SARTre, 1993, p. 53). Se o tema da literatura sempre foi o ser humano no mundo e se a liberdade almejada somente torna-se possível numa sociedade sem classes, algo utópico até o momento, o fazer literário mantém-se abstrato, pois, mesmo que o escritor seja livre para escrever tudo, o leitor não tem liberdade para concretizar a transformação.

O compromisso com o tempo histórico fica evidente nas palavras de Sartre que, como seus pares, não se coloca abaixo, nem se eleva em relação a seu tempo e, assim, alcança não apenas um número significativo de leitores, como conquista um público que se espalha por todo o mundo. Nesse sentido, como fator decorrente da consciência de seu pertencimento à sociedade e ao mundo, o escritor coloca sua arte a serviço de uma causa relacionada à vida social, política, intelectual ou religiosa de seu tempo:

O engajamento é, portanto, o ponto onde se encontram e se ligam o individual e o coletivo, onde a pessoa traduz em atos e para os outros a escolha que fez para ela mesma. Na verdade engajar-se tem a relevância de uma decisão de ordem moral, para a qual o indivíduo entende colocar de acordo a sua ação prática e as suas convicções íntimas, com todos os riscos que isso comporta (BENoît, 2003, p. 33).

A literatura não é política em sua essência, ela é política porque as questões éticas colocadas concreta e coletivamente não podem ser entendidas fora do âmbito político. Nesse aspecto, a literatura engajada distingue-se da militante, política em sua natureza. Ao compor o retrato do colonizador e do colonizado, Albert Memmi apresenta uma intrincada rede de relações, que vão muito além da dominação do primeiro sobre o segundo: a colonização enquanto processo de dominação de um povo sobre outro reclama a existência do colonizado. 
Memmi caracteriza os protagonistas do fato colonial como antíteses: à prepotência do colonizador, corresponde a subserviência do colonizado; ao lucro de um, a consecutiva pobreza do outro. Nesse processo em que o colonizador gere a vida política, social e econômica da colônia, ocorre a gradativa aceitação do colonizado. O sistema mantém-se mais pela imagem de incapaz, preguiçoso e pouco inteligente que o colonizado acaba por fazer de si próprio do que por mérito do colonizador. A situação colonial justifica a penúria do colonizado pela sua ociosidade, seu salário irrisório associa-se ao trabalho pouco rentável e sem qualificação que realiza. A escola, quando a ela tem acesso, ensina os valores da metrópole; a cultura e a história da colônia tornam-se invisíveis na estrutura colonial. Os colonizados constituem uma grande classe que desconhece ou se envergonha de seu passado, sente-se perdida no presente e não vê perspectivas para o futuro, a não ser que a utopia da independência venha a ser realidade. Eles se curvam diante de símbolos de uma nação que não é a sua, celebram heróis que são seus algozes.

Nesse contexto, inserem-se as reflexões sobre a relação entre o local e o global, as quais enfocam as práticas culturais sob a perspectiva das relações de poder:

A perspectiva analítica pós-colonial nasce também de um sentido político da crítica literária. Os estudos teóricos do pós-colonialismo tentam enquadrar as condições de produção e os contextos socioculturais em que se desenvolvem as novas literaturas. Evitam tratá-las como extensões da literatura europeia e avaliar a originalidade destas obras, de acordo com uma norma ocidental, despreocupada ou desconhecendo o seu enraizamento (LeITE, 2003, p. 13).

Nas raízes da situação pós-colonial, encontra-se uma dinâmica única: a das exigências econômicas e afetivas do colonizador, "que ocupa para ele um lugar lógico, comanda e explica cada um dos traços que empresta ao colonizado. Definitivamente, eles são todos vantajosos para o colonizador, mesmo que eles, em primeira aparência, lhe sejam danosos" (Memmi, 2007, p. 121). Ao colonizador, pouco importa o que o colonizado verdadeiramente possa ser. A imagem construída é a da falta psicológica e ética, através de uma série de negações; todas as qualidades que constituem a humanidade do colonizado degradam-se.

$\mathrm{Na}$ teoria pós-colonial, a alteridade surge a partir da noção de autoidentificação do colonizador como ligado ao colonizado, entretanto, dele diverso. Esse outro, diferente de si próprio, é o colonizado, já que o colonizador 
se caracteriza pela naturalidade e universalidade de sua cultura. Nos desenvolvimentos teóricos pós-coloniais, a referência ao outro está assente na teoria freudiana e lacaniana da subjetividade. O colonizado constrói sua identidade e alteridade a partir dos outros colonizados, em oposição ao colonizador: "O Outro (referindo-se à mãe) ou o Outro simbólico (o pai) não é uma pessoa real, mas a incorporação de pessoas constituídas em autoridade. Trata-se de um locus transcendente e absoluto, convocado cada vez em que alguém deseja falar com o outro. Na teoria pós-colonial, o Outro é o centro imperial, o discurso imperial, a metrópole" (MEMMI, 2007, p. 133).

Essa condição, entretanto, não é uma sentença condenatória ao silêncio. A voz do subalterno existe, mas por pertencer à margem, encontra dificuldade em ser ouvida no centro. A reversão de tal estado associa-se à superação da condição de objeto para a posição de sujeito. A organização coletiva, em torno de raízes culturais, é uma das formas importantes para que isso aconteça em países como Brasil, Angola e outros de língua portuguesa. No esforço de autoanálise e de recapturar a si próprio, almejando a liberdade, criam-se as condições existenciais de humanidade. A superação da subalternidade assume diferentes feições em cada país e pode ser amparada pelos saberes das ciências sociais e humanas.

A questão da identidade, enquanto imagem do eu inserido na história, é ponto de referência da literatura e das lutas empreendidas pelos países colonizados, entre eles, os de língua portuguesa. Terra e língua são explicações objetivas à reivindicação das identidades nacionais, num momento em que o separatismo surge como único meio realista de combater os efeitos de dominação, implícitos na unificação do mercado de bens culturais e simbólicos. Nesse contexto em que o sujeito se constitui enquanto se constroem as identidades das nações, cabe referência ao que Memmi chama de "a marca do plural": o colonizado é despersonalizado, caracterizado no coletivo anônimo, sempre com relevo aos aspectos negativos. Essa característica perdura nas excolônias de Portugal ainda no século Xxi, tornando-se usuais, por exemplo, referências à literatura africana que ignoram a história e cultura própria de cada um dos cinco países africanos de língua portuguesa, os quais comungam de um passado de opressão e da língua portuguesa como oficial, mas constroem suas identidades individuais sem desconsiderar os aspectos de africanidade que os unem. 
Nesse conjunto de literaturas, verifica-se a busca pela autonomia e a afirmação da identidade no contexto pós-colonial que "não designa um conceito histórico ou diacrônico, mas antes um conceito analítico que reenvia às literaturas que nasceram num contexto marcado pela colonização europeia” (LeITE, 2003, p. 11). Assim, o termo pós-colonialismo, em literatura, é consideravelmente abrangente: inclui as produções críticas, criativas e teóricas opostas à visão colonial, podendo ultrapassar os limites geográficos das ex-colônias e incluir textos literários da exmetrópole, de posição crítica sobre o colonialismo.

Autores africanos, sob o enfoque do engajamento, apresentam em seus textos o autoritarismo entre compatriotas; desvelam relações fantasmáticas, em termos de que o colonizador está aparentemente ausente, mas a exploração e o poder permanecem na sociedade descolonizada, remetendo ao neocolonialismo. Assim, a literatura das ex-colônias portuguesas declara a ausência de um "nós" que abarque a identidade angolana, moçambicana e dos demais países que vivem a mesma condição. A denúncia de uma ordem social que prolonga as iniquidades coloniais, através da opressão do africano sobre o próprio africano, das condições de pobreza e exclusão social, revela uma atitude antineocolonialista.

A literatura é uma forma de expressão do modo singular de ser e de estar no mundo do povo angolano, trazendo à luz, via texto, aspectos próprios e específicos da dinâmica cultural do país. Essa revelação configura um lugar de tensão e resistência que avança na contramão do modelo europeu. O universo a ser desvelado mostra um país cujo desenvolvimento, sempre postergado, não permite avançar no ritmo da engrenagem econômica globalizada. A via de acesso às decisões é periférica. A consciência expressa pelos escritores angolanos contemporâneos revela muitas e distintas marcas identitárias que buscam convergir para uma face em esboço permanente, contudo, constituinte de uma realidade multifacetada cultural e etnicamente.

A crítica aos costumes e comportamentos urbanos, especialmente os afetivos e sensuais entre homens e mulheres, presente em Imitação de Sartre \& Simone de Beauvoir (1999), cria um horizonte de expectativa instaurado a partir do título da obra, mas imediatamente subvertido pelo tom irônico da escrita e pelo desenlace das histórias contadas. Seguindo uma tendência pós-moderna, e afinado com a postura anticolonial, João Melo vale-se dos nomes de personalidades célebres e remete a outros textos. Não sendo possível encontrar Sartre e Beauvoir nos trópicos angolanos, encontra-se o existencialismo em 
suas personagens. O resultado consiste na reconstrução de uma memória literária, filosófica e cultural. A questão a colocar é se a subjugação da mulher e da classe social pode transformar-se em violência revolucionária e irromper em força libertadora. A leitura do texto encaminha novos questionamentos sobre a condição feminina e o ser angolano num país que busca libertar-se das amarras da colonização.

Assim também, Filhos da pátria (2008) proporciona uma viagem ao cotidiano angolano, especialmente à periferia de Luanda, onde as personagens vivem em busca da cidadania, aspiração ainda não plenamente concretizada numa realidade marcada por dificuldades de toda ordem. Essa coletânea reenvia a vários níveis de leitura, exigindo a constante desleitura do universo narrado. O sujeito individual é retratado como indivisível e indispensável para a constituição da identidade nacional, há muito buscada.

A tarefa que se pretende empreender na sequência do presente estudo consiste em identificar sob quais formas o universo angolano contemporâneo está representado nos contos de João Melo. Ao mesmo tempo, procura-se vislumbrar as múltiplas faces que se desenham nas narrativas integrantes do corpus. Nesse intuito, deve-se levar em conta a consciência da africanidade, sob a marca singular da angolanidade, como resultado do esforço de autoafirmação. No entanto, ao longo das análises a cumprir, busca-se não perder de vista os elementos estéticos, excepcionais na poética de João Melo.

Nesse contexto, assinala-se como as personagens femininas de João Melo remetem à mulher angolana, duplamente marginalizada por questões de raça e gênero, num país que conta séculos de colonização e numa sociedade tradicional, com relações de gênero fortemente consolidadas. Essa condição restringe a construção da identidade feminina no âmbito pessoal e cultural. As questões se ligam à fragmentação, deslocamento, produção, reprodução e construção de identidades que nem sempre mostram uma face nitidamente revelada, mas sugerem contornos de uma figura em construção.

Já se tornou lugar comum nos estudos literários contemporâneos afirmar que a literatura é modificada e modifica o mundo que representa. Daí decorre que, no contexto das possíveis combinações do prefixo "pós”, tão marcado pela fragmentação, os questionamentos superem as respostas, sempre sujeitas a releituras. O sujeito híbrido que se constitui nesse contexto é propenso ao autoquestionamento, especialmente se integrante de uma das minorias 
historicamente destituídas de seus direitos. O reconhecimento do passado colonial e do presente pós-colonial forma a base do conceito de identidade que se busca estabelecer pela emergência de múltiplas vozes, as quais se pretendem ouvidas.

O conflito identitário comum nas narrativas pode ser observado através da protagonista de "O estranho caso da doutora Umbelina", de Imitação de Sartre \& Simone de Beauvoir. A personagem que dá título ao conto resulta numa confluência de mundos em oposição, que buscam harmonia: de um lado, o mundo no qual a personagem passa cinco anos de sua vida estudando medicina; de outro, os valores nacionais de sua formação identitária. "A presença do branco fez com que a África se cindisse e não só se fizesse branca e negra [...], mas começasse ela própria a incorporar, assimilando-os, os valores do colonizador, questionando seu saber autóctone que passava a perceber como um menos saber" (PADilha, 2007, p. 101). A partir dessa afirmação de Laura Padilha, considera-se Umbelina como personagem em conflito entre o resíduo ancestral herdado do inconsciente coletivo angolano, a assimilação da cultura do opressor e a contribuição cultural de outros povos. A história narrada apresenta uma luandense que, ao retornar ao país, descobre que o marido tem outra mulher. Sem conseguir dissuadi-lo da ideia de ter duas mulheres, a médica, embora reticente, recorre à sabedoria dos feiticeiros.

O texto de Melo assim contempla o universo simbólico das comunidades primitivas. O mundo da protagonista caracteriza-se como o próprio mundo dionisíaco, espaço de plenitude por ela alcançado. $\mathrm{O}$ conto revela, através da personagem Mã Fifas, que a tradição é uma forma de valorizar a diferença e a resistência, expondo o desejo de "reangolonização", algo necessário no contexto do país refratado pelo texto ficcional. O feiticeiro, morador do musseque, sem endereço, não faz parte do mundo oficial, assim como a cultura que representa. Nos bairros pobres em torno do centro de Luanda, encontra-se a resistência cultural. Em meio à ausência de infraestrutura, a solução que se apresenta é buscar amparo num passado de plenitude. A situação narrada no texto mostra a impossibilidade de traçar fronteiras rigorosas entre o mundo moderno e o tradicional. Ressalve-se que os avanços científicos e tecnológicos chegam aos países colonizados com relativo atraso, fazendo com que a inserção de um povo num determinado momento histórico-cultural não seja dada pela questão cronológica. Se na Europa há evidências que configuram o pós-modernismo em meados do século xx, o mesmo não se verifica em países africanos. 
A manutenção de práticas de magia e invocação de entidades mitológicas não pode ser entendida como atraso cultural, mas integram uma parte do patrimônio cultural de África. O que se destaca é sua hibridação, o entrecruzamento com os hábitos trazidos pelo colonizador. No caso de Umbelina, pode-se interpretar a valorização da tradição como tentativa de resgatar um passado perdido, no qual autenticidade e autonomia estão presentes e contribuem para que se revele um eu afinado com as origens da Angola livre, no momento pré-colonial.

Do plano individual, alcança-se a noção de identidade nacional, considerando a nação como um sistema de representação cultural que produz sentidos. A nação enquanto comunidade simbólica, no dizer de Benedict Anderson, retomado por Stuart Hall, é uma "comunidade imaginada". Ou seja, um discurso que influencia e organiza as ações e concepções que o indivíduo tem de si mesmo. Os sentidos constituídos consideram as "estórias" contadas sobre a nação e as memórias que conectam presente e passado. A narrativa da nação representa as experiências que conectam a vida do indivíduo ao destino nacional, preexistente. Além disso,

há a ênfase nas origens, na continuidade, na tradição e na intemporalidade. A identidade nacional é representada como primordial - "está lá, na verdadeira natureza das coisas", algumas vezes adormecida, mas sempre pronta para ser "acordada" de sua "longa, persistente e misteriosa sonolência”, para reassumir sua inquebrável existência. Os elementos essenciais do caráter nacional permanecem imutáveis, apesar de todas as vicissitudes da história (HALL, 2005, p. 53).

No caso de Angola, considera-se que a cultura nacional pós-colonial recua a um tempo perdido, quando a grandiosidade da nação se fazia inconteste. Diferentemente de ato passivo, esse retorno oculto revela a luta para buscar o eu coletivo original, tanto quanto possível. A partir dessas considerações, traz-se para o campo analítico a existência da médica-pediatra recém-formada que, no retorno a Luanda, descobre o relacionamento nada secreto de seu marido com Tina. Em "O estranho caso da doutora Umbelina”, o leitor já é prevenido logo à entrada do texto: estranho, mas não se espera tanto.

Numa situação que remete ao inusitado, não há lógica ou essa precisa ser entendida no contexto cultural da personagem, diferente dos padrões europeus de emancipação feminina. A inquietação amplia-se: ao se desencontrar com o outro, estão as personagens a se encontrarem consigo próprias? Veja-se então: influenciada pela tia a valer-se dos ensinamentos de um quimbanda (feiticeiro, 
adivinho), a personagem mostra-se indecisa, julga que a parente deve "ultrapassar essas ideias de feitiço, quimbandas... São ideias antigas, tia! A revolução... (Um muxoxo da velha, sibilino como a cuspidela de uma serpente, cortou o comício que Umbelina iniciara)" (Melo, 1999, p. 104).

Instala-se o choque centre ciência/ideais revolucionários e tradição. Contudo, decidida a buscar o conhecimento do mais velho, a médica faz um passeio por Luanda. Parece redescobrir seu espaço, que traz à lembrança um mundo abandonado, mas ainda muito presente. Umbelina deixa marido e filho para buscar a formação profissional. Ao regressar, depara-se com duas situações adversas: a traição do marido e o país envolto em pobreza, mutilado pela guerra. "O que posso eu fazer com estas crianças? Devem passar fome em casa, não têm água potável, vivem no meio do lixo... A saúde começa por aí!... Merda, quando é que esta guerra acaba? Quando é que os sul-africanos nos deixam em paz?” (Melo, 1999, p. 105).

A personagem é construída como mulher contraditória: assume seu papel social e se sente submissa ao esposo. Através do trabalho, Umbelina participa da Organização da Mulher Angolana (OMA), mas em casa, vive para satisfazer as implicâncias do marido, segundo ela, um "homem angolano atrasado, um machista, um complexado". Essa caracterização decorre das ações da personagem masculina, reveladoras de seu complexo de inferioridade: "Lá tens um curso superior, não penses que me pode utilizar, camarada doutora... [...] Chefe de departamento de uma empresa estatal, fiava-se na militância para subir socialmente. "Um dia ainda assumo a empresa!" costumava dizer" (MELO, 1999, p. 108-109).

Ao adentrar no universo de Mã Fifas, a narrativa assume características cômicas: veja-se a indicação para chegar à casa do quimbanda. A descrição deixa dúvidas acerca da existência efetiva do lugar. Não há surpresas na chegada das mulheres; como adivinho, Fifas já sabe de tudo e sentencia que a "paciente" deverá ficar em sua presença por uma semana. O choque de Umbelina diante do feiticeiro prenuncia grande transformação: depois que "desconseguiu" vomitar, fica enebriada com "uma luz doce... Os olhos dele irradiam uma estranha calma, quase assassina...” (Melo, 1999, p. 110).

Decorrido o tempo solicitado por Mã Fifas, a tia vai ao encontro da sobrinha, sem nenhum espanto: "nas mãos que alonga para tocar a sobrinha, como se quisesse reconhecê-la, nos olhos com que perscruta, implacável, a 
felicidade reencontrada de Umbelina, no coração cansado prestes a explodir, como se de novo tivesse nascido" (Melo, 1999, p. 111).

A nova ou antiga Umbelina dirige-se à tia: "Já estou embora curada, mais-velha. Não duvida, então! O Mã Fifas fez mesmo um tratamento bem faine, agora me sinto aliviada daqueles calundus, estou do mais tóti, juro mesmo!" (Melo, 1999, p. 112).

Umbelina já não é a médica, assume a identidade dos antepassados, num ritual entre místico e cômico, que remete a uma dimensão mais profunda, como se o inconsciente coletivo de um povo aflorasse nas ações de uma mulher, exemplificado também pela linguagem que a personagem passa a utilizar.

Como sabido, as teorias pós-coloniais assumem relevância no sentido de serem instrumentos para estabelecer o diálogo com outros textos, escritos num contexto de margem, neocolonizados, como no caso das nações africanas de língua portuguesa, em seu momento pós-colonial. A relação dialógica evidenciada torna falso imaginar que essas realidades isolam-se do mundo ou estão fechadas em si mesmas. Assim, há nos textos produzidos pelos escritores desses países, especialmente aqueles de cunho mais crítico, uma sombra da presença dos antigos impérios coloniais:

É neste sentido que importa distinguir entre o Outro cuja história colocada sob rasura acaba por dar consistência narrativa ao Eu dividido na pós-modernidade e esses outros Outros que assombram a representação já nem de sujeitos divididos mas de Eus negados enquanto tal, constituídos como perda de si [...] pela subjugação a narrativas-mestras legitimadoras da modernidade europeia, entre estas a da nação, que implica [..] uma ordem cambiante mas persistente de inclusões e exclusões (Ferreira, 2006, p. 93).

O conto "O estranho caso da doutora Umbelina" recoloca a questão das identidades das nações e das literaturas africanas de língua portuguesa, pois nele o indivíduo livre sinaliza a possibilidade de uma nação igualmente livre. O passeio por Luanda traz à tona a identidade primeira da personagem, o processo de cura realizado pelo feiticeiro faz emergir uma nova mulher. Umbelina "sentiu-se, pela primeira vez em toda a sua existência, protegida contra todos os males e perigos. Invencível” (Melo, 1999, p. 112). A voz adormecida durante a longa noite de espera ecoa pela pátria angolana, livre como a mulher que reencontra sua identidade.

A diversidade étnica e cultural de Angola é um contrassenso à própria concepção europeia de nação, entendida mais como grupo racial e étnico 
do que politicamente organizado. Nesse cenário multifacetado e conturbado, permeado por contradições, emerge uma literatura de cunho engajado, comprometida com a afirmação de uma identidade que represente os diferentes grupos étnico-culturais angolanos. A obra literária Filhos da pátria, de João Melo, apresenta histórias de existências vividas sob a angústia e tensão em meio à miséria, contexto que se deve à herança colonial, acentuada pela elite que governa o país nos primeiros tempos de independência e ainda o complexo momento histórico contemporâneo.

O conto "O elevador" possibilita a identificação de resquícios coloniais na sociedade angolana pós-colonial. A história narrada, baseada em fatos rememorados pela personagem Pedro Sanga, tem a duração cronológica limitada ao tempo em que o elevador faz o percurso para chegar ao destino da personagem: o oitavo andar. A estrutura textual, organizada em nove fragmentos, simula a trajetória pelos andares e leva ao desfecho que se desenrola no terraço.

O narrador em terceira pessoa assume declarada posição políticoideológica, aspecto evidenciado logo ao início da narrativa quando apresenta o leitmotiv que conduz a existência de Pedro Sanga: "Até onde é capaz de ir a capacidade de humilhação do ser humano? É tão grande como a sua capacidade de adaptação? E, adaptação - o que é exactamente? Sim, o que é ser ou estar adaptado" (Melo, 2008, p. 9).

O questionamento acerca da adaptação leva a refletir sobre o momento histórico no texto, revelador de uma situação ainda não explicitada, a que o narrador apresenta resistência, expressa pelo forte tom de ironia:

status quo (expressão que infelizmente tem caído em desuso, talvez porque, nos tempos que correm o status quo, é só um, ou seja, perdeu o quo, transformando-se em estado unânime e universal, também chamado global, de tal maneira que hoje praticamente mais ninguém luta contra o status quo, a não ser que tenha suficiente força anímica para suportar os rótulos pouco abonatórios com que passará imediatamente a ser designado), é não fazer ondas? É ser dócil, mesmo quando se é espezinhado? (MELo, 2008, p. 9).

Na sequência narrativa, o leitor é informado de que, no elevador, há "um exemplar autóctone da estética neobarroca que, segundo alguns, caracteriza a pós-modernidade" (Melo, 20o8, p. 11). Trata-se de uma mulher cujo destino é o mesmo de Pedro Sanga: encontrar-se com o dono do escritório que fica na 
cobertura do prédio. Ao associar a figura bizarra à Angola do futuro, o narrador cria um efeito cômico:

Uma cabeleira loira visivelmente artificial, a blusa vermelha semitransparente deixando apreciar quase totalmente os seios (se é que aqueles seios tipo ovo estrelado são dignos de qualquer apreciação!...) colants de leopardo justinhos às coxas e uns sapatos altíssimos, azuis e doirados, que mal a mantêm equilibrada (Melo, 2008, p. 10).

A personagem Pedro Sanga vive uma perturbação psicológica, observada no conflito de consciência revelado pelo jogo de sinônimos para a condição de adaptado. Pedro Sanga afirma que adaptação é luta, capacidade de enfrentar o mundo, denúncia contra as imperfeições do mesmo. A recordação da guerra pela libertação nacional traz ao contexto narrado a personagem Soares Manoel João, um radical defensor da independência de Angola, que busca inspiração em Agostinho Neto. Ao longo dos andares que se sucedem, a memória de Pedro Sanga evoca os diferentes momentos da vida de Soares Manoel João, cuja identificação começa pelo sobrenome português.

Inicialmente, Soares é caracterizado como Funje com Pão, um idealista que projeta um país onde

seria criado "um homem novo", que tem a missão de identificar o socialismo científico, o regime mais avançado da humanidade, onde todos os homens são iguais, nem burgueses, nem proletários, nem brancos, nem mulatos "e muitos menos bailundos" (Melo, 2008, p. 15).

Após a vitória dos revolucionários, a personagem torna-se o Camarada Excelência que, "misturando, de forma desconexa, mas convicta, uma retórica marxista absolutamente vulgar, mal colada a cuspe, com violentos sentimentos raciais e tribais" (MeLo, 2008, p. 15), revela toda contradição das primeiras ações governamentais do novo país.

Valendo-se das condições incipientes da nação recém criada e de sua capacidade de "organização", o ex-lutador pela independência torna-se um dos primeiros capitalistas autóctones angolanos. Note-se através da personagem Soares/Funje com Pão/Camarada Excelência a exemplificação da situação já referida por Fanon (1979) ao abordar a relação colonizador/colonizado. Em Condenados da terra, o autor analisa a violência física, cultural e psíquica empreendida pelo colonizador para desumanizar o sujeito colonial. O restabelecimento da dignidade do colonizado ocorre pela violência, 
mais especificamente, a elite nacional que, ao tomar o poder, apropria-se das riquezas e torna-se cúmplice dos valores coloniais, consolidando princípios eurocêntricos, mesmo que isso signifique espoliar a própria nação.

A personagem Pedro Sanga afirma de si para si: "Um homem é um homem, um bicho é um bicho!” (Melo, 20o8, p. 10). A expressão evoca uma personagem de Graciliano Ramos, em sua obra literária Vidas secas: Fabiano, um nordestino tão adaptado às condições em que vive, a ponto de perder a dignidade humana, afirma: "Você é um bicho". Pedro Sanga, ao contrário, reage e luta: quer ser homem, plenamente humano. Sua batalha é contra a corrupção do governo de Angola. Da mesma forma, o poeta Manuel Bandeira alude à animalização do ser humano no poema "O bicho": "Vi, ontem / na imundície do pátio / um bicho que catava comida entre os detritos [...] O bicho não era um cão / não era um gato / não era rato / o bicho, meu Deus, era um homem”. Os escritores, em diferentes países, evocam a perda da dignidade, decorrente da humilhação sofrida.

Ainda no conto em análise, dois dias antes dos episódios narrados, o protagonista recebe uma proposta para facilitar negociações da empresa de Soares com o Ministério em que Sanga detém o cargo de Secretário. Pressionado pela mulher, que o chama de burro, que não sabe adaptar-se e nem se organizar (entenda-se é honesto), Pedro hesita em seguir sua viagem pelo prédio. Note-se que a personagem está no elevador,

um dos artefactos que, para recorrer a uma expressão popular, "o colono levou" após a independência do país - informe-se que, nos últimos tempos, começaram a ser edificados alguns prédios completamente novos na cidade, os quais, naturalmente, estão apetrechados com esses equipamentos e não só (MELo, 2008, p. 13).

O elevador, metáfora da presença do colonizador, conduz Pedro a seu destino: aceitar a proposta e adaptar-se aos olhos dos outros enquanto, para si próprio, significa humilhar-se. A pedra não resiste e sucumbe ao impacto do status quo pós-colonial.

Humilhado e, finalmente adaptado, Pedro ainda participa da comemoração com o antigo amigo, agora um "gajo" que se dirige à mulher do elevador num arremedo de francês, coincidentemente, sua amante: "Fosefine, mon amour, viens ici!" (Melo, 2008, p. 25). O pesadelo de Pedro Sanga, conduzido do chão de Angola ao alto de um moderno prédio, mexe com suas entranhas: "Apenas teve tempo de correr e agarra-se a um dos parapeitos do terraço, começando a 
vomitar, sem parar, cada vez mais agoniado. Enquanto o seu vômito se espalhava, ajudado pela brisa, pelas ruas adjacentes" (Melo, 2008, p. 26).

A cena narrada deixa transparecer a posição do narrador evidenciada em vários momentos da história. A postura crítica mostra que é patriota quem concorda com a estrutura ou aceita as regras herdadas do colonizador, cuja ruptura torna-se um desafio, como se observa quando Pedro sente-se incapaz de deixar o "aparelho" e prossegue sua angustiante trajetória. A palavra aparelho refere-se ao elevador, mas pode também ser entendida no contexto da estrutura política na qual, segundo o narrador,

todos os dias nos deparamos com uma quantidade considerável de radicais que, na prática, renega as suas próprias teses ou então - o que constitui o outro lado da moeda - passa a defender com o mesmo radicalismo teses diametralmente opostas (MeLo, 2008, p. 17).

Os questionamentos do narrador, destacados pela marca dos parênteses, colocam-se como diálogo com o leitor. Nessas falas, expõe-se uma defesa de Pedro Sanga, pela qual nutre simpatia e através dela, expressa sua posição ideológica. A viagem transforma-o no outro, antes repelido, agora assimilado. Não havendo o outro, fragmenta-se o eu e, consequentemente, fragmenta-se a identidade do indivíduo e da pátria imaginada real após a independência. Pedro Sanga torna-se a "pedra no meio do caminho" do franco avanço da corrupção.

A relação semântica do nome da personagem remete também a um elemento muito expressivo da cultura angolana, a Grande Mãe da Criação, deusa mítica em África, que se revela em três símbolos amplos de sua procedência: a árvore, a terra e a pedra. João Melo elege a última como elemento que fica subjacente ao texto, Pedro (pedra) Sanga (cântaro de barro em kimbundu) é da terra, do chão da pátria, não é das alturas, por outros edificada. Não é um indivíduo que vê sua história ser escrita pelos valores que repele. O conto inicial, a exemplo de outros da coletânea, põe em questão um aspecto mais amplo:

Mas o que será amanhã deste país, se os autoproclamados herdeiros de fortunas anteriormente inexistentes e todos os acumuladores primitivos de capital, os neofundamentalistas, os pseudointelectuais e os medíocres de toda a sorte continuarem a ocupar todos os espaços assim? (Melo, 2008, p. 12).

O leitor é deixado pelo narrador no alto do prédio, de onde passa a visualizar as demais narrativas do livro. 
É nesse cenário que se desenrola a história de "O feto". O conto é narrado pela protagonista não identificada pelo nome. A personagem passa a ser uma metonímia das adolescentes angolanas que fazem da prostituição o meio de sobrevivência pelas ruas de Luanda. A protagonista dirige-se a um interlocutor indefinido, que pode ser o próprio leitor. A narrativa é um relato-justificativa para o fato de a adolescente ter jogado o feto abortado no lixo. A linguagem do texto, sendo coloquial, revela o emprego de grande número de termos próprios do português angolano. A voz inicialmente firme e determinada - "É verdade mesmo, esse feto que está aí no chão esvaindo-se totalmente no meio do lixo era meu mesmo sim senhor" (Melo, 20o8, p. 147) - vai perdendo o tom agressivo até transformar-se em lamento, à semelhança de um choro infantil, à medida que os fatos são narrados.

A história de vida da personagem não difere de tantas outras existências marcadas pela guerra civil angolana: "Minha mãe mesmo é que me mandou na rua mas não vale a pena lhe condenarem só atoa, aqui mesmo no nosso contexto quem é que pode atirar pedra nas costas dos outros" (Melo, 2008, p. 147). Aos 13 anos, a pedido da mãe, a menina passa a se prostituir. Nesse mundo, em que a dignidade não tem valor, a menina-moça logo descobre que "os homens não são homens, são bichos” (MELo, 2008, p. 149). Essa adjetivação refere-se também ao pai que agride a mãe; a situação é deveras complexa para que se aponte um culpado, ao que a personagem afirma: "eu só queria correr, fugir outra vez, ir no colo da minha mãe, voltar na nossa casa no mato" (MELo, 2008, p. 149).

Percebe-se que a volta ao passado sem sofrimento não é uma simples evasão no tempo. Trata-se de uma estratégia de sobrevivência num meio pleno de hostilidade e sofrimento. O presente oferece uma sucessão de dores de toda ordem, ampliadas pela hipocrisia, que parece também infinita. Veja-se, a título de exemplo, a descrição do primeiro "cliente" da personagem:

o velho que me tinha acabado de descabaçar, um italiano que está cá a serviço de uma organização que auxiliava as crianças abandonadas, olhos sombrios e bigode cínico, barriga ligeiramente avantajada e mãos cheias de pelos, pôs-se a rir como um porco enquanto dizia mama mia, mama mia afinal és virgem, minina, afinal és virgem (MELo, 2008, p. 150).

É possível estabelecer relação com a imagem do estrangeiro e a figura do lobo mau, temor das crianças e que, para essa adolescente angolana, converte-se numa realidade marcada pela dor. A imagem buscada no conto 
infantil remete ao colonizador do passado, agora disfarçado de ativista, embora não se pretenda aqui fazer julgamentos, tampouco condenações.

A invocação de um elemento da fé cristã, especialmente, a imagem de Nossa Senhora, a mãe que vela por todos seus filhos de fé, é mais do que irônica, atentando contra a dignidade de criatura, de ser integrante do universo da adolescente explorada. Nenhum argumento mais se faz necessário para justificar a presença do feto no lixo. Como pode uma sociedade, tal como a representada, cobrar qualquer atitude de responsabilidade de uma pessoa maltratada em todas as dimensões de sua existência?

A revolta expressa em falas, como "o que eu não admito é que me chamem comerciante do sexo, se eu estou nessa vida é porque preciso, só eu sei o meu sofrimento" (Melo, 2008, p. 151). Contudo, por mais que expresse indignação, a personagem tem consciência de que não há esperança:

eu ainda só tenho quinze anos, deixo fazer tudo, também o que querem que eu faça se a minha casa do mato lhe incendiaram na guerra, o fogo destruiu tudo, a memória do meu pai, a coragem da minha mãe, os meus sonhos e o meu destino (MeLo, 2008, p. 151).

O sentimento de desesperança e falta de perspectiva pode ser resumido em: "não sinto nada, aliás, absolutamente nada, apenas um grande vazio" (MELo, 2008, p. 151). A sensação agora é de conformismo, apatia e indiferença:

desde que tive de abandonar às pressas a minha casa do mato nunca mais que pude ter sonhos, por isso jamais me vinguei dos homens que me têm feito sofrer, a não ser ontem, quando joguei esse feto que está aí no lixo para ser comido pelos ratos, baratas e cães (MeLo, 2008, p. 152).

Não há sentimento materno em relação ao feto nas condições em que vive a personagem: "Um filho sem pai ou com buerêrê de pais não é um filho, é uma desgraça, o que é que queriam que eu fizesse" (Melo, 2008, p. 153).

A tensão da narrativa, somada a uma voz que fala intermitentemente, coloca o leitor na situação de interação com o universo narrado. Mais do que isso, a fala emprestada à personagem oprimida, sem intermediação, imprime um ritmo alucinante à narrativa; a vida da protagonista é transformada e destruída pela guerra e toda sorte (expressão irônica no contexto narrado) de flagelos dela decorrentes. O texto apresenta a forma de monólogo, dirigindo-se a um interlocutor que assume a condição de testemunha passiva, numa espécie de transferência de silêncio. Para as personagens, a única forma de interação 
com o mundo é a revolta expressa pela agressão e violência. $\mathrm{O}$ aborto praticado pela adolescente ilustra essa afirmação e, além disso, sem as mínimas condições de higiene, revela a completa desumanidade, como atesta a fala da personagem: "não sei mesmo porquê que não morri, porra, berrei desalmadamente como as cabras que o meu pai desventrava lá no mato antes de virmos na cidade" (Melo, 2008, p. 153).

A presença da mídia oferece à cena ares de espetáculo (de horror). A reação da personagem é de estupefação: um mundo que lhe volta as costas, de repente, percebe sua existência por meio da violência praticada por ela. Não há explicação para a repercussão que o acontecimento provoca: "a morte de um feto não é notícia, sobretudo tratando-se de um feto angolano, pois como está a vida em Angola é melhor morrer dentro da placenta do que sobreviver e ter de sofrer como eu e minha mãe estamos a sofrer” (Melo, 2008, p. 154).

Mobilizam-se ongs, padres, polícia, todo um exército de pessoas falsamente preocupadas com o bem-estar da "ex-mãe" ou do feto morto. A hipocrisia toma conta e, simultaneamente, o medo surge. Não constitui novidade o lado mais fraco ser sempre o culpado e o único a sofrer punição. A personagem luta, argumenta: "como é que vocês não compreendem isso se estão todas horas a dizer que Deus escreve certo por linhas tortas, um feto é um ser humano, quem disse" (Melo, 2008, p. 154). O cerco se fecha, os muitos olhos a julgar, a cobrar, intimidam a adolescente de 15 anos. O relato da personagem faz-se contundente, assume a totalidade da narrativa que se encerra sobre a densidade anunciada. $\mathrm{O}$ infratexto, à medida que se revela, retoma os contos anteriores e o título do livro. A questão remete à ambivalência: o autor apresenta filhos sem pátria ou, na inexistência da pátria, não há filhos?

A resposta pode ser buscada nessa personagem emblemática quando se dirige à mãe, também vítima e, por isso, incapacitada de qualquer reação: "eu só quero paz, quero sentar-me no teu colo e adormecer como antigamente quando estávamos no mato antes da guerra chegar, quero sossego e tranquilidade, quero regressar de novo para o interior da tua placenta, mãe" (Melo, 2008, p. 155).

Uma possibilidade se anuncia, ainda que metaforicamente: o renascimento para o indivíduo e a reconstrução para Angola. A condição que se coloca para tanto é a ruptura com a herança colonial que cobre de sombras o momento pós-colonial e abre espaço para que o neocolonialismo se instale sob formas variadas. 
A identidade que emerge desse contexto é fragmentada e múltipla, não no sentido do multiculturalismo, mas no respeito às diferenças presentes na constituição identitária de Angola. Tampouco se constrói uma identidade de nação vislumbrando o passado e a tradição, elementos imprescindíveis, entretanto, não bastantes. O momento contemporâneo pressupõe um diálogo entre culturas, aspecto evidenciado pelo tom interdiscursivo observado nas narrativas que dialogam com a cultura e o espaço brasileiro; o autor cita o Sindicato das Prostitutas do Rio de Janeiro, algo impossível de ser imaginado pela narradora de "O feto".

A afinidade entre Angola e Brasil é mais ampla do que a referência interdiscursiva ou o compartilhamento de uma língua oficial comum. O Brasil é o destino da maioria dos africanos arrancados de sua terra para serem escravos nas Américas. Dada a origem desse grande contingente, que passa a formar a população brasileira, para muitos estudiosos, "Angola é a mãe do Brasil”, considerando a marca biológica e cultural angolana verificada na nação tupiniquim. Se a afirmação vale para caracterizar o passado, no momento pós-colonial, pode-se afirmar que o Brasil é o irmão mais velho de Angola. A independência brasileira conquistada ainda no século xix tornou o país americano uma referência para as colônias africanas, especialmente, as lusitanas.

A exposição do processo de composição das narrativas é característica da autorreflexividade e metáfora da organização da sociedade que representam. O narrador-autor articula os textos de forma parcial, revelando opiniões e posições ideológicas em diálogo com o narrador-personagem que assume sua "bisbilhotice", ao mesmo tempo que orienta a leitura através do uso de parênteses explicativos. As histórias narradas revelam, através do microcosmo pessoal ou familiar, uma estrutura mais ampla: a nação angolana.

De forma sutil, a natureza textual remete a um mundo enunciado que, relido, concretiza o recurso paródico, no que tem de status ideológico. Em vários contos da coletânea, observa-se a presença de narradores que não cansam de estabelecer diálogo com um leitor projetado no texto, ou mesmo, de fazer um autoquestionamento que remete não apenas à situação da criação do texto, como se projeta em nível de autorreferencialidade. Sob essa ótica, fixa-se o laço paródico: não se trata de um narrador titubeante, é a própria função da arte e, por extensão, da 
literatura, que está sendo questionada no contexto enunciado. Numa sociedade como a angolana do período pós-colonial, a criação literária impregna-se de ideologia. No caso particular do escritor em análise, o comprometimento com os ideais de justiça e igualdade torna-se mais evidente à medida que se sucedem as páginas dos dois livros analisados.

Em sentido mais abrangente, o macrocosmo refratado mostra uma nação desafiada a permitir que seus habitantes sejam cidadãos de uma pátria livre e, nessa condição, que seus filhos aspirem à liberdade individual. A organização discursiva e as estratégias textuais observadas nos textos em análise constituem elementos de um texto literário engajado, que supera a questão da crítica social e se insere no campo de uma literatura que, sem abdicar dos recursos estilísticos, remete à questão da liberdade em sua dimensão mais ampla.

A análise empreendida identific a um discurso marcado pelo questionamento e pela denúncia de valores opressivos, impostos por uma história de colonização e dominação cujo processo de reversão se inicia a partir da descolonização e se estende à atualidade. Mais do que identificar espaços vazios e silêncios, a proposta literária pós-colonial busca o rompimento com suas causas; num enfrentamento da política do silêncio, atribui a esse uma forma de produção de sentidos. A construção da identidade não se totaliza, é por natureza dinâmica e abrange novos questionamentos, em ciclos que se refazem através de textos literários em diálogo intenso com a história e a cultura popular. A literatura, comprometida em desenhar a face identitária do povo de Angola, alia um tempo recuado e um tempo prospectivo, em que os ideais que motivam a luta pela libertação assentam-se para dar suporte à identidade que, uma vez construída, busca reconhecimento.

Por tudo isso, João Melo é um escritor comprometido com o que escreve, sem neutralidade em relação às personagens e enredo. A exploração de estereótipos e a denúncia de padrões e estruturas neocoloniais constrói um painel representativo de comportamentos femininos e masculinos não limitados a Angola, remete a seres humanos de qualquer lugar do mundo e, de forma mais aproximada, refere-se aos cinco povos africanos de língua portuguesa. Sob a contística pós-colonial de João Melo, Angola se apresenta com face múltipla e diferentes tons de vozes, a constituir uma pátria em que a utopia da liberdade, tal como lido na obra, possa um dia tornar-se realidade: 
ANDrÉ Luis Mitidieri

Rejane Seitenfuss Gehlen

"abraçaram-se energicamente, sacudiram os braços um do outro, voltaram a abraçar-se..." (MELo, 2001, p. 167).

\section{Referências}

Benoît, Denis. Literatura e engajamento: de Pascal a Sartre. Tradução de Luiz Dagobert de Aguirra Roncari. Bauru: Edusc, 2002.

FAnon, Frantz. Os condenados da terra. Tradução de José Laurêncio de Melo. Prefácio de JeanPaul Sartre. 2. ed. Rio de Janeiro: Civilização Brasileira, 1979.

Ferreira, Ana Paula. Fantasmas insepultos: raça, racismo, nação, In: LARAnjeIrA, José Pires; Simões, Maria João. Xavier, Lola Geraldes (Org.). Estudos de literaturas africanas: cinco povos, cinco nações. Coimbra: Novo Imbondeiro, 2006. p. 91-95.

Hall, Stuart. A identidade cultural na pós-modernidade. Tradução de Tomaz Tadeu da Silva e Guacira Lopes Louro. 10. ed. Rio de Janeiro: DPびA, 2005.

LARANJEIRA, José Pires. Ensaios afro literários. 2. ed. Lisboa: Novo Imbondeiro, 2005.

LeIte, Ana Mafalda. Literaturas africanas e formulações pós-coloniais. Lisboa: Colibri, 2003.

Melo, João. Imitação de Sartre \& Simone de Beauvoir. Lisboa: Caminho, 1999.

Melo, João. Filhos da pátria. Lisboa: Caminho, 2001.

Melo, João. Filhos da pátria. Rio de Janeiro: Record, 2008.

Memmi, Albert. Retrato do colonizado precedido de retrato do colonizador. Tradução de Marcelo Jacques de Moraes. Rio de Janeiro: Civilização Brasileira, 2007.

Padilha, Laura Cavalcante. Entre voz e letra: o lugar da ancestralidade na ficção angolana do século xx. Niterói: Eduff, Rio de Janeiro: Pallas, 2007.

SArtre, Jean- Paul. O que é a literatura. Tradução de Carlos F. Moisés. 2. ed. São Paulo: Ática, 1993.

Recebido em 19 de fevereiro de 2017.

Aprovado em 2 de março de 2017.

\section{Resumo/Abstract/Resumen}

\section{Colonialismo e anticolonialismo em contos angolanos de João Melo}

André Luis Mitidieri

Rejane Seitenfuss Gehlen

A presente análise busca relacionar as obras literárias Imitação de Sartre \& Simone de Beauvoir e Filhos da pátria, de autoria do escritor angolano João Melo, com o colonialismo e o anticolonialismo, que são diretamente implicados ao pós-colonialismo. A literatura pós-colonial reflete sobre a condição periférica e sua relação contextual. Como aspecto colonialista a ser considerado, na primeira das coletâneas de contos referidas, tem-se a 
dominação masculina e, na segunda, a organização da elite angolana pós-independência. Como aspecto anticolonialista, tem-se, no primeiro livro, o pensamento de Simone de Beauvoir acerca da condição feminina, através da busca pela emancipação das personagens femininas e, no segundo, as questões da identidade nacional e individual.. O engajamento sartriano, redimensionado sob a perspectiva pós-colonialista, apresenta-se como estratégia antineocolonialista, fazendo frente ao neocolonialismo, representado pela antiutopia contemporânea e pelo formalismo pós-moderno, subvertido pela metalinguagem, pela paródia e pela reversão de suas expectativas de leitura, na contística de Melo.

Palavras-chave: Angola, anti(neo)colonialismo, engajamento sartriano, identidade cultural, pós-colonialismo, João Melo.

\section{Colonialism and anticolonialism in João Melo's angolan tales}

André Luis Mitidieri Rejane Seitenfuss Gehlen

This analysis aims at relating the short story collections Imitação de Sartre \& Simone de Beauvoir and Filhos da pátria, written by the Angolan fictionist João Melo, to the colonialism and the anticolonialism, which are directly implicated with post-colonialism. Post-colonial literature reflects about the peripheral condition and its contextual relation. As a colonialist aspect to be considered, there is the male domination in the first of these collections of short stories and the organization of the Angolan post-independence elite in the second of them; as anticolonialist, the thoughtfull about the female condition of Simone de Beauvoir through the pursuit of the emancipation of female characters in the first book, and the national and individual identity issues in the second one. Sartrian engagement, resized under post-colonialist perspective, presents itself as an anti neocolonialist strategy, challenging the neocolonialism, represented by the contemporary dystopia and the postmodern formalism, this one subverted by the metalanguage, the parody and the reversion of its reading expectations, in the reasoning of Melo.

Keywords: Angola, anti(neo)colonialism, Sartrian engagement, cultural identity, postcolonialism, João Melo.

\section{Colonialismo y anticolonialismo en cuentos angoleños de João Melo}

André Luis Mitidieri

Rejane Seitenfuss Gehlen

Este análisis busca relacionar las obras literarias Imitação de Sartre \& Simone de Beauvoir y Filhos da pátria, de la autoría del escritor angoleño João Melo, con el colonialismo y el anticolonialismo, que están directamente asociados con el poscolonialismo. La literatura poscolonial reflexiona sobre la condición periférica y su relación contextual. Como un aspecto colonialista a ser considerado, en la primera de las recopilaciones de cuentos tenemos la dominación masculina, y en la segunda, la organización de la élite 
angoleña posterior a la independencia. Como aspecto anticolonialista, en el primero de los livros tenemos el pensamiento acerca de la condición femenina de Simone de Beauvoir, a través de la búsqueda de la emancipación de los personajes femeninos, y en el segundo, las cuestiones de la identidad nacional e individual. El "compromiso" sartriano, redimensionado bajo la perspectiva poscolonial, se presenta como una estrategia antineocolonialista, posicionada contrariamente al neocolonialismo, representado por la antiutopía contemporánea y por el formalismo posmoderno, subvertido por el metalenguaje, por la parodia y por la reversión de sus expectativas de lectura en los cuentos de Melo.

Palabras clave: Angola, anti(neo)colonialismo, compromiso sartriano, identidad cultural, poscolonialismo, João Melo. 